
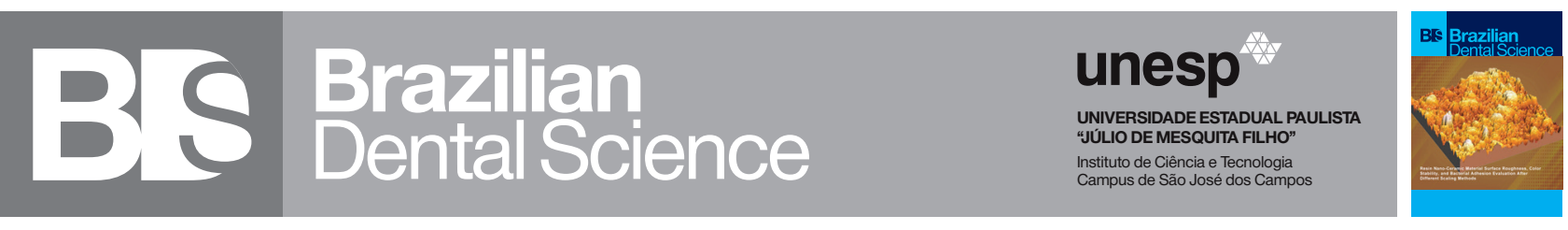

\title{
Assessing Knowledge, Practices, Use and Raising Awareness of Antibiotic And Antibiotic Resistance Among Dental Patients Before and After Educational Sessions
}

Avaliação de conhecimentos, práticas, uso e conscientização sobre antibióticos e resistência a antibióticos entre pacientes odontológicos antes e depois das sessões educacionais

Mahassen Mohamed FARGHALY ${ }^{1}$, Amira Saad BADRAN ${ }^{1}$, Khaled KERAA ${ }^{1}$

1 - Faculty of Oral \& Dental Medicine, Misr International University, Cairo, Egypt.

\section{ABSTRACT}

Objectives: Education and awareness-raising are global health policy tools to modify public behavior towards antibiotic resistance. Considering the high frequency of antibiotic use and self-medication in Egypt, together with the lack of an awareness agenda, our objectives were to assess the knowledge and practices related to antibiotic use and resistance among patients attending dental clinics, and to evaluate the changes in knowledge following a specially designed one-on-one educational session. Material and Methods: A convenience sample of 310 dental patients participated in this study. A modified questionnaire was used to assess knowledge and practices related to antibiotic use and resistance. Second-year dental students were trained to administer the questionnaire and to use the educational materials they designed to raise awareness. Following the education session, patients completed another similar questionnaire to assess the changes in their knowledge. Results: Increasing awareness of antibiotic resistance can be an effective way to address the antibiotic resistance crisis. More than half of the participants (55.6\%) did not know whether antibiotics treat diseases caused by bacterial or viral infections. The majority of participants $(85.5 \%)$ had taken antibiotics during the last year, and (50.5\%) of them had taken the same antibiotic more than once. Higher educational levels of the participants were significantly associated with a higher level of knowledge. Statistically significant increase in the percentages of correct answers to all questions were observed after the educational sessions. Conclusion: The one-on-one educational session is an effective approach to address the antibiotic resistance crisis.

\section{KEYWORDS}

Antibiotic use; Antibiotic resistance; Knowledge; Practices; Dental patients; Awareness and education; Sustainable development goals.

\section{RESUMO}

Objetivos: Educação e conscientização são ferramentas de política de saúde global para modificar o comportamento do público em relação à resistência aos antibióticos. Considerando a alta frequência de uso de antibióticos e automedicação no Egito, juntamente com a falta de uma agenda de conscientização, nossos objetivos foram avaliar o conhecimento e as práticas relacionadas ao uso de antibióticos e resistência entre pacientes atendidos em clínicas odontológicas, e avaliar as mudanças em conhecimento após uma sessão educacional especialmente projetada para este assunto. Material e Métodos: Uma amostra de 310 pacientes odontológicos participou deste estudo. Um questionário modificado foi usado para avaliar o conhecimento e as práticas relacionadas ao uso e resistência a antibióticos. Os alunos do segundo ano do curso de odontologia foram treinados para aplicar o questionário e usar os materiais educacionais que elaboraram para aumentar a conscientização. Após a sessão educacional, os pacientes responderam a outro questionário semelhante para avaliar as mudanças em seus conhecimentos. Resultados: Aumentar a conscientização sobre a resistência aos antibióticos pode ser uma forma eficaz de lidar com a crise de resistência aos antibióticos. Mais da metade dos participantes $(55,6 \%)$ não sabia se os antibióticos tratam doenças causadas por infecções bacterianas ou virais. A maioria dos participantes $(85,5 \%)$ havia tomado antibiótico no último ano e (50,5\%) deles havia tomado o mesmo antibiótico mais de uma vez. O maior nível de escolaridade dos participantes foi significativamente associado a um maior nível de conhecimento. Aumentos estatisticamente significativos nas porcentagens de respostas corretas para todas as questões foram observados após a sessão educacional. Conclusão: A sessão educacional individual é uma abordagem eficaz para lidar com a crise de resistência aos antibióticos.

\section{PALAVRAS-CHAVE}

Uso de antibióticos; Resistência a antibióticos; Conhecimento; Práticas; Pacientes odontológicos; Conscientização e educação; ODS. 


\section{INTRODUCTION}

A ntibiotic resistance has increasingly been recognized as a main concern in global healthcare [1]. It is becoming obvious that the whole world is heading towards a "postantibiotic era" [2]. This realization directed the World Health Organization (WHO) to identify antibiotic resistance as a major threat to public health security in 2007 [3]. Although antibiotic resistance is an inevitable, naturally occurring process, the speed of the process has been accelerated due to the misuse of antibiotics among humans and animals $[4,5]$. The decreased effectiveness of antibiotics compromises our ability to treat the most common bacterial diseases. It also undermines many other advances in health and medicine [4,6]. Quantifying the economic and social burdens related to antibiotic resistance is complicated, but some estimates have been attempted and shown startling outcomes [7,8]. According to the World Bank, "antibiotic-resistant infections could hinder the achievement of Sustainable Development Goals (SDGs) and push 28 million people into poverty by 2050" [6]. Such massive costs may jeopardize efforts for sustainable economic growth as emphasized in SDG 8. It also undermines efforts to eradicate poverty and hunger (goals 1 \& 2) especially in Low and Middle Income countries, where $25 \%-70 \%$ of total income is spent on healthcare; making medicines the largest family cost after food. Additionally, improving water and sanitation services will reduce the need for antibiotics and reduces spread of resistant bacteria as emphasized in goal 6 . We need to keep antibiotics effective to be able to treat infectious diseases - this is essential to achieve good health and wellbeing as illustrated in Goal 3. Finally, and most importantly there is an urgent need to educate and raise awareness of both health professionals in their early educational years as well as the public about Antimicrobial Resistance (AMR) to achieve the adopted targets of quality education in goal 4 [9].
The International Pharmaceutical Federation (FIP) and the WHO outlined strategic objectives that emphasized the importance of effective communication, education and awareness campaigns in response to antibiotic resistance $[3,6]$. Similarly, One Health and Small World launched initiatives aimed to tackle the antibiotic crisis and produce new knowledge to reduce the development of antimicrobial resistance $[10,11]$. Several studies have reported that the behavior of the public, the antibiotic prescribing behavior of healthcare professionals, and the irrational use of antibiotics especially in children and dental patients are all contributing to the increase in antibiotic resistance $[1,12,13]$. Thus, education and awareness-raising have been positioned as primary tools in global health policy to modify public behavior and target antimicrobial resistance [14]. Different strategies have been used to educate the public in several countries; one of the trials was in England where public poster campaign was adopted with positive messages on how the public could help themselves when they had common cold. This was reinforced by health professionals who were encouraged to give patients clear information about the expected duration of symptoms, selfcare, and benefits and harms of antibiotics [15]. In Thailand, awareness campaigns for the public were part of a national action plan that aimed to increase the public knowledge of antibiotic resistance and awareness of appropriate use of antibiotics by $20 \%$ by the year $2021[14,16]$. Worth mentioning is the Small World Initiative and Tiny Earth education programs in the USA that tackled the antibiotic crisis by a crowd sourcing strategy, based on active learning for young students together with dissemination of the antibiotic awareness guidelines of the WHO. [11] Because of wide cross-national differences in antibiotic use, little is known about the general public's use of antibiotics and knowledge of antibiotic resistance at the global level $[4,7]$. However, previous studies have revealed that the 
prevalence of antibiotic resistance is elevated in countries with excessive use of non-prescription antibiotics where people can obtain antibiotics based on self-medication and exerting pressure on health workers [6,17-19]. According to the WHO's multi-country public awareness survey, the frequency of antibiotic use in Egypt is the highest in the world, with $76 \%$ of respondents having taken antibiotics in the last six months [4]. Despite the fact that Egyptian law includes measures for controlling the dispensation of antibiotics, yet there are no active governmental policies to regulate such a process [20]. This has led to increased reported levels of antimicrobial resistance to nearly all tested antibiotics among a total of 126 non-duplicate gram-negative isolates that were recovered from different clinical samples taken from hospitalized Egyptian patients in 2014 [21]. In countries where antibiotic resistance is high, the recent literature has reported low levels of awareness about antibiotic resistance [22-24]. Consequently, there have been many calls to understand the knowledge and practices of the public in such countries and to record the levels of improper usage in populations that self-medicate, in order to develop suitable educational and interventional strategies targeting antibiotic resistance $[7,16]$. Accordingly, the current study aimed to assess the knowledge and practices related to antibiotic use and resistance among patients attending the Misr International University (MIU) Dental Clinics in Egypt and to evaluate changes in knowledge among those patients following a specially designed educational session about antibiotic use, practices and resistance.

\section{METHODS}

Participants were patients visiting the MIU Dental Clinics for examination or continuation of treatment. The sample size was calculated from the 9400 patients who attend the MIU Dental Clinics Complex on average each year, and the percentage of Egyptian respondents who had heard the term "antibiotic resistance", which was reported to be $22 \%$ in the WHO Library Catalogue (2015) [4]. Using a 5\% margin of error and an alpha level $=0.05$, the minimum estimated sample size was 263 participants. The sample size was increased to 310 subjects, which allowed each participant to be interviewed by one dental student. Calculations were performed using StatCalc formulas in Epi Info 7.2.2.2 software. A convenience sampling technique was used to recruit adult patients above 18 years of age; both genders and different socio-economic levels. Only patients with mental disorders or hearing or vision problems were excluded from the study, because the educational session included verbal and visual aids. The study received ethical approval from the MIU Institutional Review Board (MIU-IRB1718-050) in accordance with the guidelines of the Helsinki Declaration.

Protocol is registered at ClinicalTrials. gov: ID: NCT04493008. Before data collection, the objectives of the study were presented to the participants and written consent was obtained. Each participant was informed that withdrawal from the study was acceptable and that withdrawal would not result in cessation of their treatment. Second-year dental students interviewed and educated the participants while they waited for their scheduled appointments. The study was conducted during the 20172018 academic year. Prior to the study, students received comprehensive and interactive educational sessions that focused on the causes of antibiotic resistance, malpractice and improper prescriptions by dental professionals and the role of dentists in educating the public in the context of public health course. They were also trained to lead the face-to-face interviews and instructed to develop and create different educational materials aiming at increasing awareness of antibiotic uses and understanding of antibiotic resistance. The educational material was in the form of catchy posters, calendars with daily tips, and interactive pocket notes with simple information. The 
educational materials were evaluated by staff members and were later discussed in a one-onone educational session before distribution to the patients. Our data collection instrument was a modified version of a WHO questionnaire [4]. Some questions were added by the students as part of their training in designing questionnaires in the public health course. Before the study, the questionnaire was tested on fifteen patients. Accordingly, some questions were reformulated, while others were deleted, to establish the version that was used in the study. The questionnaire included four sections; socio-demographic characteristics, assessment of knowledge level about antibiotics, with four questions based on a nominal scale, practices and self-reported use of antibiotics using five questions based on a nominal scale. The fourth section was split into two parts: knowledge of antibiotic resistance comprising three questions on nominal scale, whereas the second part aimed to assess the participants' knowledge about actions to minimize the danger of antibiotic resistance. The questions were answered on a 5-point Likert scale. The administration of the pre-test questionnaire was followed by a one-on-one, detailed educational session, and finally, each patient completed a post-test questionnaire, which was the same as the pre-test questionnaire, except that the history of antibiotic use section was omitted from the post-test questionnaire.

\section{STATISTICAL ANALYSIS}

Numerical data were presented as mean and standard deviation values. Categorical data were presented as frequencies and percentages. The Wilcoxon signed-rank test was used to compare knowledge about antibiotics before and after the educational intervention. A linear regression model was used to determine the significant predictors of antibiotic knowledge scores. The regression coefficients and 95\% confidence intervals (CIs) were calculated. The significance level was set at $p \leq 0.05$. A multivariate regression model was used to determine the significant predictors of the use of antibiotics. A binary logistic regression model was used to determine the significant predictors of familiarity with the term "antibiotic resistance". The regression coefficients, odds ratios (ORs) and the 95\% CIs for the ORs were calculated. Statistical analysis was performed with IBM SPSS Statistics for Windows (version 23.0.; IBM Corp, Armonk, NY).

\section{RESULTS}

The recruited sample comprised 121 men (39\%) and 189 women (61\%). The mean age ( \pm standard deviation) was 39 ( \pm 10.5 ) years; the participants' ages ranged from 18 to 73 (95\% CI: 37.8-40.3) years old. Demographics relating to educational level, occupational status and social status are presented in Table I.

Table I - Frequencies (n) and percentages (\%) of demographic data

\begin{tabular}{|c|c|c|}
\hline Demographic data & n/310 & \% \\
\hline 1. Educational level: & & \\
\hline a. Uneducated & 53 & 17.1 \\
\hline b. Primary education & 15 & 4.8 \\
\hline c. Preparatory education & 26 & 8.4 \\
\hline d. Secondary school/mid-level education & 107 & 34.5 \\
\hline e.University graduate & 67 & 21.6 \\
\hline f. No answer & 42 & 13.5 \\
\hline 2. Occupation: & & \\
\hline a. Unemployed & 4 & 1.3 \\
\hline b. Housewife & 132 & 42.6 \\
\hline c. Student & 3 & 1 \\
\hline d. Blue collar & 64 & 20.6 \\
\hline e. White collar & 58 & 18.7 \\
\hline f. Retired & 1 & 0.3 \\
\hline g. No answer & 48 & 15.5 \\
\hline 3. Social status: & & \\
\hline a. Single & 35 & 11.3 \\
\hline b. Married & 208 & 67.1 \\
\hline c. Divorced & 13 & 4.2 \\
\hline d. Widowed & 12 & 3.9 \\
\hline e. No answer & 42 & 13.5 \\
\hline
\end{tabular}


Regression model was constructed to determine the significant predictors of antibiotic knowledge. The dependent variable was the average score on the knowledge questions before the education session. Each correct answer was scored (1) while the incorrect answer was scored (0) then the total score of each patient was calculated. The independent variables were demographics and previous history of antibiotic sensitivity. Education was found to be the only statistically significant predictor of antibiotic knowledge (regression coefficient $=0.032$, p-value $=0.004,95 \%$ CI: 0.010-0.053), suggesting that participants with higher educational levels had higher knowledge scores than those with lower educational levels. The mean \pm standard deviation values for the knowledge scores were $0.41 \pm 0.27,0.37 \pm$ $0.3,0.47 \pm 0.34,0.56 \pm 0.31,0.54 \pm 0.3$ and $0.56 \pm 0.28$ for subjects with no education, primary, preparatory, secondary, mid-level and university education, respectively (Figure 1). Multivariate regression results showed that education level had a statistically significant effect on the use of antibiotics according to a doctor's advice (regression coefficient $=0.415$, p-value $=0.003,95 \%$ CI: $0.385-0.561)$. The percentages of subjects who used antibiotics according to a doctor's advice by education level were as follows: $19.6 \%, 5.8 \%, 10.6 \%$, $10.6 \%, 27.5 \%$ and $25.9 \%$ for subjects with no education, primary, preparatory, secondary, mid-level and university education, respectively (Figure 2). A binary logistic regression model was constructed to determine the significant predictors of familiarity with the term "antibiotic resistance". The dependent variable was having heard the term (yes/no), while the independent variables were demographics and previous history of antibiotic sensitivity. Age was the only statistically significant predictor of having heard of the term "antibiotic resistance" (regression coefficient $=0.067$, p-value $=0.004, \mathrm{OR}=1.069$ with 95\% CI: 1.021-1.120). Older participants had higher odds of having heard of the term "antibiotic resistance" than younger subjects. Participants who had heard the term aged 42.8 \pm 10.8 years old, while participants who had not heard the term "antibiotic resistance" were $38 \pm$ 10 years old. There were statistically significant increase in the percentages of participants who provided correct answers to each of the questions regarding knowledge about antibiotics after the educational session (Table II).

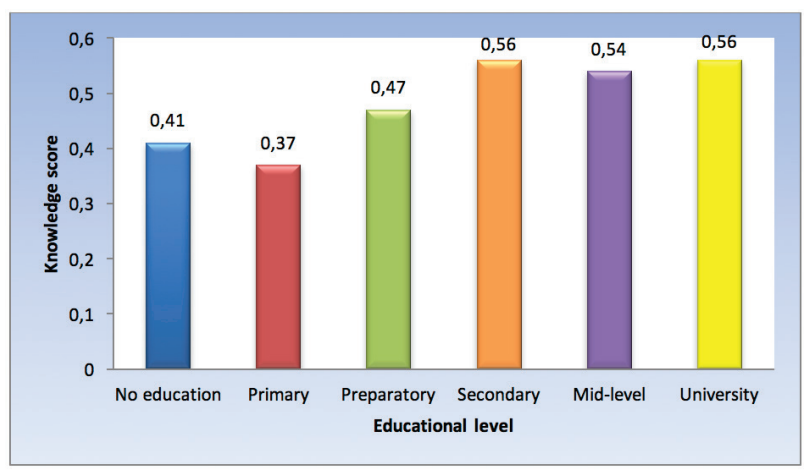

Figure 1 - Mean antibiotics knowledge score of patients with different educational levels before educational sessions.

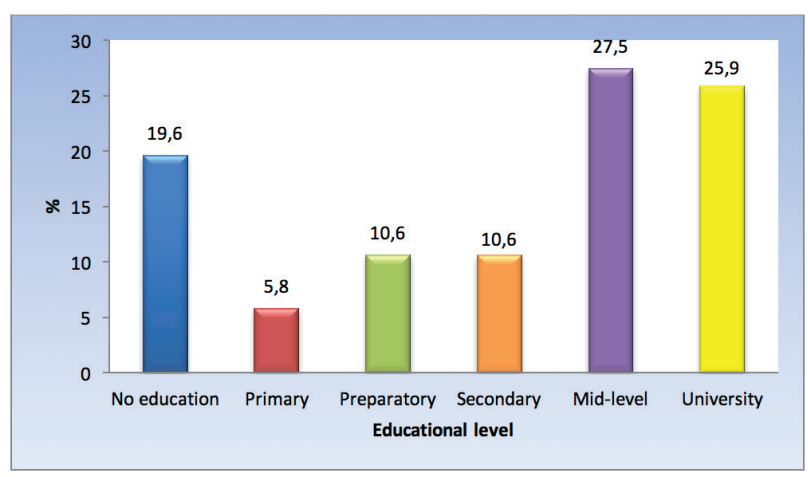

Figure 2 - Percentage of patients with different educational levels who used antibiotics according to a doctor's advice. 
Table II - Frequencies (n), percentages (\%), 95\% Confidence Interval, and results of marginal homogeneity test for comparison between knowledge about antibiotic questions before and after educational sessions

\begin{tabular}{|c|c|c|c|c|c|c|}
\hline \multirow{2}{*}{$\begin{array}{l}\text { Knowledge about } \\
\text { antibiotics }\end{array}$} & \multicolumn{2}{|c|}{$\begin{array}{c}\text { Before } \\
\text { education }\end{array}$} & \multicolumn{2}{|c|}{$\begin{array}{c}\text { After } \\
\text { education }\end{array}$} & \multirow{2}{*}{ p-value } & \multirow{2}{*}{$\begin{array}{l}95 \% \mathrm{Cl} \\
\text { for the } \\
\text { change }\end{array}$} \\
\hline & $n / 310$ & $\%$ & $\mathrm{n} / 310$ & $\%$ & & \\
\hline \multicolumn{7}{|c|}{ 1. Antibiotics are used for treatment of diseases caused by: } \\
\hline a. Bacteria & 106 & 34.2 & 238 & 76.8 & & \\
\hline b. Viruses & 37 & 11.9 & 19 & 6.1 & $<0.001^{\star}$ & $\begin{array}{l}35.5- \\
49.7 \%\end{array}$ \\
\hline c. Don'tknow & 167 & 53.9 & 53 & 17.1 & & \\
\hline
\end{tabular}

2. When should you stop taking antibiotics once you have begun treatment?

\begin{tabular}{|c|c|c|c|c|c|c|}
\hline a. When you feel better & 136 & 43.9 & 44 & 14.2 & & \\
\hline $\begin{array}{l}\text { b. When you finish the } \\
\text { prescribed dose }\end{array}$ & 147 & 47.4 & 253 & 81.6 & $0.009^{*}$ & $27.2-41.2 \%$ \\
\hline c.Don't know & 27 & 8.7 & 13 & 4.2 & & \\
\hline
\end{tabular}

3. It is okay to use the same antibiotic that helped you getting better when you had the same symptoms before.

$\begin{array}{ccccccc}\text { a. Yes } & 125 & 40.3 & 78 & 25.2 & & \\ \text { b. No } & 147 & 47.4 & 219 & 70.6 & 0.001^{*} & \begin{array}{c}15.7- \\ 30.7 \%\end{array} \\ \text { c.Don'tknow } & 38 & 12.3 & 13 & 4.2 & & \\ \end{array}$

4. It's okay to use antibiotics that were given to a friend or family member, as long as they were used to treat the same illness.

$\begin{array}{ccccccc}\text { a. Yes } & 72 & 23.2 & 27 & 8.7 & & \\ \text { b. No } & 218 & 70.3 & 274 & 88.4 & 0.031^{\star} & 11.9-24.3 \% \\ \text { c. Don'tknow } & 20 & 6.5 & 9 & 2.9 & & \end{array}$

*: Significant at $p \leq 0.05$, Answers in bold are the correct answers

Two-hundred and sixty-five participants (85.5\%) reported they had used antibiotics within the past year, $2.9 \%$ reported they had never used antibiotics before and $11.6 \%$ could not remember the last time they used antibiotics (Table III).
Table III - Frequencies (n), percentages (\%) and 95\% Confidence Intervals of responses to use of antibiotic questions

\begin{tabular}{|c|c|c|c|}
\hline Use of antibiotics & $\mathbf{n}$ & $\%$ & $95 \% \mathrm{Cl}$ \\
\hline \multicolumn{4}{|l|}{ 1. When did you last take antibiotics? } \\
\hline a. In the last month & $146 / 310$ & 47.1 & $41.4-52.8 \%$ \\
\hline b. In the last 6 months & $70 / 310$ & 22.6 & $18-27.6 \%$ \\
\hline c. In the last year & $23 / 310$ & 7.4 & $4.8-10.9 \%$ \\
\hline d. More than a year ago & $26 / 310$ & 8.4 & $5.6-12 \%$ \\
\hline e. Never & $9 / 310$ & 2.9 & $1.3-5.4 \%$ \\
\hline f. Can't remember & $36 / 310$ & 11.6 & $8.3-15.7 \%$ \\
\hline \multicolumn{4}{|c|}{ 2. On that occasion, how many times did you use it? } \\
\hline a. Once & $86 / 265$ & 32.5 & $26.9-38.5 \%$ \\
\hline b. Twice & $63 / 265$ & 23.8 & $18.8-29.4 \%$ \\
\hline c. Three-four times & $33 / 265$ & 12.5 & $8.7-17 \%$ \\
\hline d. More than four times & $43 / 265$ & 16.2 & $12-21.2 \%$ \\
\hline e.Can't remember & $40 / 265$ & 15.1 & $11-20 \%$ \\
\hline \multicolumn{4}{|c|}{ 3. On that occasion, did you use it according to doctor's advice? } \\
\hline a. Yes & $232 / 265$ & 87.5 & $83-91.3 \%$ \\
\hline b. No & $29 / 265$ & 10.9 & $7.5-15.3 \%$ \\
\hline c. Can't remember & $4 / 265$ & 1.5 & $0.4-3.8 \%$ \\
\hline \multicolumn{4}{|c|}{ 4. Do you read the pamphlet enclosed within the antibiotic package? } \\
\hline a. Yes & $219 / 301$ & 72.8 & $67.4-77.7 \%$ \\
\hline b. No & $64 / 301$ & 21.2 & $16.8-26.3 \%$ \\
\hline c. Don'tcare & $18 / 301$ & 6 & $3.6-9.3 \%$ \\
\hline \multicolumn{4}{|c|}{ 5. If you had skipped an antibiotic dose; you should: } \\
\hline a. Double the next dose & $66 / 310$ & 21.3 & $16.9-26.3 \%$ \\
\hline b. Consult a doctor or pharmacist & $135 / 310$ & 43.5 & $38-49.3 \%$ \\
\hline c. Don't know what to do & $109 / 310$ & 35.1 & $29.8-40.8 \%$ \\
\hline
\end{tabular}

Meanwhile, only (24.2\%) had heard the term "antibiotic resistance". The majority of them (53.3\%) heard it from a doctor or pharmacist, while $20 \%$ had heard about it from the media (Figure 3). 


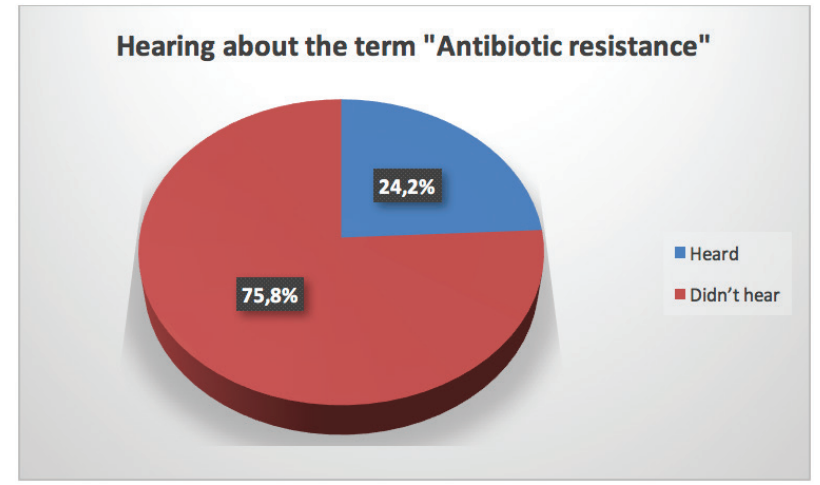

Figure 3 - Percentage of participants who heard or didn't hear about the term "Antibiotic resistance".

Participants who had heard about antibiotic resistance $(n=75)$ were asked six questions about the actions that would help address the problem of antibiotic resistance. After the educational session, all participants $(n=310)$ answered these questions (Table IV).

Table IV - Percentages for knowledge about actions that would help address the problem of antibiotic resistance before and after education (Before awareness $n=75$, after awareness $n=310)$

\begin{tabular}{|c|c|c|c|c|c|c|c|}
\hline \multirow{2}{*}{$\begin{array}{l}\text { Actions that } \\
\text { would help } \\
\text { address the } \\
\text { problem of } \\
\text { antibiotic } \\
\text { resistance }\end{array}$} & \multirow[t]{2}{*}{$\begin{array}{c}\text { Aware- } \\
\text { ness }\end{array}$} & \multicolumn{3}{|c|}{$\begin{array}{cc} & \text { Neither } \\
\text { igree } & \text { agree } \\
\text { ightly } & \text { nor } \\
& \text { disagree }\end{array}$} & $\begin{array}{c}\text { Disagree } \\
\text { slightly }\end{array}$ & \multirow{2}{*}{$\begin{array}{c}\text { Disagree } \\
\text { strongly } \\
\\
\%\end{array}$} & \multirow{2}{*}{$\begin{array}{c}\text { Don't } \\
\text { know } \\
\%\end{array}$} \\
\hline & & $\%$ & $\%$ & $\%$ & $\%$ & & \\
\hline \multirow{2}{*}{$\begin{array}{l}\text { 1. People should } \\
\text { use antibiotics } \\
\text { only when they are } \\
\text { prescribed by a } \\
\text { doctor }\end{array}$} & Before & 77.3 & 12 & 5.3 & 2.7 & 1.3 & 1.3 \\
\hline & After & 89 & 7.7 & 1 & 0.3 & 1 & 1 \\
\hline \multirow{2}{*}{$\begin{array}{l}\text { 2. People should } \\
\text { not keep antibiotics } \\
\text { and use them later } \\
\text { for other illnesses }\end{array}$} & Before & 24 & 13.3 & 10.7 & 26.7 & 22.7 & 2.7 \\
\hline & After & 36.1 & 19.3 & 8.1 & 12.6 & 22.6 & 1.3 \\
\hline \multirow{2}{*}{$\begin{array}{l}\text { 3. People should } \\
\text { wash their hands } \\
\text { regularly }\end{array}$} & Before & 84 & 10.7 & 27 & 0 & 0 & 2.7 \\
\hline & After & 84.2 & 12.6 & 3.2 & 0 & 0 & 0 \\
\hline \multirow{2}{*}{$\begin{array}{l}\text { 4. Parents should } \\
\text { make sure all of } \\
\text { their children's } \\
\text { vaccinations are } \\
\text { up-to-date }\end{array}$} & Before & 89.3 & 5.3 & 27 & 0 & 0 & 2.7 \\
\hline & After & 91 & 7.7 & 0.6 & 0 & 0 & 0.6 \\
\hline \multirow{2}{*}{$\begin{array}{l}\text { 5. Doctors should } \\
\text { only prescribe } \\
\text { antibiotics when } \\
\text { they are needed }\end{array}$} & Before & 68 & 18.7 & 2.7 & 5.3 & 2.7 & 2.7 \\
\hline & After & 71.9 & 19.7 & 3.2 & 1.9 & 0.3 & 2.9 \\
\hline \multirow{2}{*}{$\begin{array}{l}\text { 6. Pharmaceutical } \\
\text { companies should } \\
\text { develop new } \\
\text { antibiotics }\end{array}$} & Before & 54.7 & 14.7 & 13.3 & 4 & 2.7 & 10.7 \\
\hline & After & 57.1 & 16.8 & 12.6 & 5.5 & 0 & 8.1 \\
\hline
\end{tabular}

\section{DISCUSSION}

Antibiotic resistance is one of the main threats to global health and to the world's sustainable development. Actions can be implemented at all levels of society, including the public [4]. The current paper examines the knowledge and practices related to antibiotic use and antibiotic resistance in a sample of dental patients in Egypt - which has extraordinarily high rates of antibiotic self-medication [20,21]. Although, there are numerous previous studies that have assessed knowledge and practices related to antibiotic use and resistance in many countries, yet very few of them were among dental patients in Egypt. The findings of the current study emphasize that a good start could be to develop interventions through raising peoples' awareness of the risk of misuse of antibiotics and to eradicate misconceptions about antibiotic usage. The characteristics of the 310 participants indicate a higher participation of women than men in the study, with the majority of participants being house wives, followed by blue, then white collar jobs. Although gender and age groups were not significantly associated with knowledge regarding antibiotic use, yet higher educational levels were significantly associated with a higher level of knowledge. Similar findings have been reported by other studies that assessed the knowledge and practices of the general public related to antibiotics $[7,17]$. Therefore, community-based plans may have an important role in mitigating the gap in knowledge and practices between populations with different educational levels. Previous studies attributed antibiotics' misconceptions to the tendency of health providers to prescribe antibiotics to avoid complications, relieve symptoms or fulfill patients' demands $[4,6]$. Notably, in this study, there were statistically significant increases in the percentages of correct answers to all questions regarding knowledge about antibiotics after the educational session, which highlights the impact of the one-on-one sessions and shows that people 
are eager to know and learn more about this topic. This finding is consistent with other studies that administered long term educational sessions to the public and reported noticeable outcomes on awareness, while the effect on attitudes and irrational use of antibiotics was weak [12-14]. This suggests that changes in awareness and knowledge could better be achieved via detailed one-on-one educational sessions, yet the change in attitude and behavior needs comprehensive social and behavioral techniques.

The majority of participants $(85.5 \%)$ had taken antibiotics during the last twelve months. This percentage is higher than the recorded levels in other neighboring countries, including $75 \%$ in Saudi Arabia [14] and 76\% in Sudan during the last six months [4]. Extremely positive findings were observed related to reading the enclosed pamphlet in the antibiotic package and consulting a doctor or a pharmacist if a dose was skipped. The majority of participants reported they took antibiotics following medical advice. Nevertheless, it is important to note that a degree of bias is possible, as respondents may have provided the answers they believed were expected. Similar results were obtained in other surveys in which the authors had similar concerns about patients providing the answers they thought were correct rather than providing the true answers $[3,4,18]$.

Few participants reported that they had heard the term "antibiotic resistance"; almost half of these participants had heard it from doctors or pharmacists, and few had heard it from the media. Therefore, an important role is played by health personnel as a source of information to the public and contributors to the scientific material presented in the media. Age was the only statistically significant predictor of having heard of the term "antibiotic resistance", this may be due to the higher possibility of the older age group having visited doctors and interacted with pharmacists for health issues. Following the educational session, participants' knowledge about the actions that would help addressing the problem of antibiotic resistance was notably satisfactory. These findings are particularly promising in that the educational session was held only once for each patient, contrary to all other studies where public education relied on repeated, long term group education [13-15]. Yet, similar findings were achieved in the current study concerning the change in knowledge. Thus, emphasizing the effectiveness of the oneon-one educational method. This method gives participants the chance to ask questions and discuss misconceptions, and as such, it improves participants' knowledge.

\section{LIMITATIONS}

There are some limitations that must be considered when interpreting the findings. Foremost, the convenience sampling design used in the study limits the generalizability of the results to a national scale. In addition, the closed-ended questions restricted the degree to which we could investigate respondents' answers to identify their levels of understanding. Finally, recall and social desirability biases might have resulted from the use of self-reporting. Despite these limitations, the obtained findings offer an update on the public's knowledge of antibiotic use and antibiotic resistance.

\section{CONCLUSION}

Everyone in the community should have awareness of proper antibiotic usage and the critical consequences of antibiotic misuse, regardless of his or her educational or economic status. The one-on-one educational session is an effective approach to address the antibiotic resistance crisis, and could be adopted by all health professionals to alter public behavior towards antibiotic resistance.

\section{Recommendations}

A similar study on a national scale is suggested to present more inclusive and reflective 
insights into the current condition of antibiotic usage and awareness of antibiotic resistance. Health providers should educate the public on the rational use of antibiotics. It is important to educate and raise awareness of health professionals in their early educational years about antibiotic resistance, malpractice and improper prescriptions.

\section{Acknowledgements}

We would like to thank participants who eagerly devoted part of their valuable time to the study and the dental students who performed the interviews. Special thanks go to the administration of the Dental Clinics Complex for organizing the research process without jeopardizing the patients' schedules.

\section{Conflict of interest statement}

The authors declare no conflict of interest.

\section{Funding}

The study was funded by MIU.

\section{REFERENCES}

1. André M, Vernby A, Berg J, Lundborg CS. A survey of public knowledge and awareness related to antibiotic use and resistance in Sweden. J Antimicrob Chemother. 2010 Jun;65(6):1292-6. doi: 10.1093/jac/dkq104. Epub 2010 Apr 1.PMID: 20360063.

2. MasonT, Trochez C, Thomas R, Babar M, Hesso I, Kayyali R. Knowledge and awareness of the general public and perception of pharmacists about antibiotic resistance. BMC Public Health 2018;18:711. https://doi. org/10.1186/s12889-018-5614-3

3. Hassali MA, Arief M, Saleem F, Khan MU, Ahmad A, Mariam W, et al. Assessment of attitudes and practices of young Malaysian adults about antibiotics use: a cross-sectional study. Pharm Pract (Granada). $2017 \mathrm{Apr}-$ Jun;15(2):929. doi: 10.18549/PharmPract.2017.02.929. Epub 2017 Jun 30. PMID: 28690695; PMCID: PMC5499350.

4. WHO Library Cataloguing-in-Publication Data. Antibiotic resistance: Multicountry public awareness survey. Geneva: World Health Organization; 2015.

5. Ancillotti M, Eriksson S, Veldwijk J, Nihlén Fahlquist J, Andersson Dl, Godskesen T. Public awareness and individual responsibility needed for judicious use of antibiotics: a qualitative study of public beliefs and perceptions. BMC Public Health. 2018 0ct 3;18(1):1153. doi: 10.1186/s12889018-6047-8. PMID: 30285689; PMCID: PMC6171135.

6. Bassoum 0, Sougou NM, Diongue M, Lèye MMM, Mbodji M, Fall D, et al. Assessment of general public's knowledge and opinions towards antibiotic use and bacterial resistance: a cross-sectional study in an urban setting, Rufisque, Senegal. Pharmacy (Basel). 2018 Sep 20;6(4):103. doi: 10.3390/pharmacy6040103. PMID:30241307; PMCID: PMC6306938.
7. Tshokey T, Adhikari D, Tshering T, Wangmo S, Wangdi K. Assessing the knowledge, attitudes, and practices on antibiotics among the general public attending the outpatient pharmacy units of hospitals in bhutan: a cross-sectional survey. Asia Pac J Public Health. 2017 0ct;29(7):580-8. doi: 10.1177/1010539517734682. Epub 2017 Oct 9. PMID: 28990398.

8. Wozniak TM, Barnsbee L, Lee XJ, Pacella RE. Using the best available data to estimate the cost of antimicrobial resistance: a systematic review. Antimicrob Resist Infect Control. 2019 Feb 1;8:26. doi: 10.1186/s13756-0190472-z. PMID: 30733860; PMCID: PMC6359818.

9. Jasovský D, Littmann J, Zorzet A, Cars 0 . Antimicrobial resistance-a threat to the world's sustainable development. Ups J Med Sci. 2016 Aug;121(3):159-64. doi: 10.1080/03009734.2016.1195900. Epub 2016 Jul 14. PMID: 27416324; PMCID: PMC4967260.

10. Léger A, Stärk KDC, Rushton J, Nielsen LR. A one health evaluation of the university of copenhagen research centre for control of antibiotic resistance. Front Vet Sci. 2018 Aug 21;5:194. doi: 10.3389/fvets.2018.00194. PMID:30186842; PMCID: PMC6110841.

11. Valderrama MJ, González-Zorn B, de Pablo PC, Díez-Orejas R, FernándezAcero T, Gil-Serna J, et al. Educating in antimicrobial resistance awareness: adaptation of the Small World Initiative program to servicelearning. FEMS Microbiol Lett. 2018 Sep 1;365(17). doi: 10.1093/femsle/ fny161. PMID: 29982335.

12. Topor G, Grosu IA, Ghiciuc CM, Strat AL, Lupu oru CE. Awareness about antibiotic resistance in a self-medication user group from Eastern Romania: a pilot study. PeerJ. 2017 Sep 12;5:e3803. doi: 10.7717/peerj.3803. PMID: 28924507; PMCID: PMC5600173.

13. Zhang Y, Kabba J, Chang J, Ji W, Zhu S, Yu J, et al. A school-based educational intervention for school-aged children and caregivers about rational use of antibiotics in urban areas of Shaanxi Province: a study protocol for a randomized controlled research. Int J Environ Res Public Health. 2018 Sep 3:15(9):1912. doi: 10.3390/ijerph15091912. PMID: 30720793; PMCID: PMC6163849.

14. Haenssgen MJ, Xayavong T, Charoenboon N, Warapikuptanun P, Khine Zaw Y. The consequences of AMR education and awareness raising: outputs, outcomes, and behavioural impacts of an antibiotic-related educational activity in Lao PDR. Antibiotics (Basel). 2018 Nov 1;7(4):95. doi: 10.3390/antibiotics7040095. PMID: 30388824; PMCID: PMC6316454.

15. McNulty CA, Cookson BD, Lewis MA. Education of healthcare professionals and the public. J Antimicrob Chemother. 2012 Jul;67 Suppl 1:111-8. doi: 10.1093/jac/dks199. PMID: 22855873.

16. Tangcharoensathien V, Sommanustweechai A, Chanvatik S, Kosiyaporn $\mathrm{H}$, Tisocki K. Addressing the threat of antibiotic resistance in Thailand: monitoring population knowledge and awareness. WHO South East Asia J Public Health. 2018 Sep;7(2):73-78. doi: 10.4103/2224-3151.239417.PMID: 30136664

17. Alqarni SA, Abdulbari M. Knowledge and attitude towards antibiotic use within consumers in Alkharj, Saudi Arabia. Saudi Pharm J. 2019 Jan;27(1):106-111. doi: 10.1016/j.jsps.2018.09.003. Epub 2018 Sep 5. PMID: 30662313; PMCID: PMC6323197.

18. Alghadeer S, Aljuaydi K, Babelghaith S, Alhammad A, Alarifi MN . Self-medication with antibiotics in Saudi Arabia. Saudi Pharm J. 2018 Jul:26(5):719-24. doi: 10.1016/j.jsps.2018.02.018. Epub 2018 Feb 6. PMID: 29991916; PMCID: PMC6035317.

19. Torres NF, Chibi B, Middleton LE, Solomon VP, Mashamba-Thompson TP Evidence of factors influencing self-medication with antibiotics in low and middle-income countries: a systematic scoping review. Public Health. 2019 Mar;168:92-101. doi:101016/.jpuhe.2018.11.018. Epub 2019 Feb 1. PMID: 30716570 . 
20. Khalifa HO, Soliman AM, Ahmed AM, Shimamoto T, Nariya H, Matsumoto T, et al. High prevalence of antimicrobial resistance in gram-negative bacteria isolated from clinical settings in Egypt: recalling for judicious use of conventional antimicrobials in developing nations. Microb Drug Resist. 2019 Apr;25(3):371-385. doi: 10.1089/mdr.2018.0380. Epub 2019 Jan 25. PMID: 30681401.

21. Zakaa El-Din M, Samy F, Mohamed A, Hamdy F, Yasser S, Ehab M. Egyptian community pharmacists' attitudes and practices towards antibiotic dispensing and antibiotic resistance; a cross-sectional survey in Greater Cairo. Curr Med Res Opin. 2019 Jun;35(6):939-46. doi: 10.1080/03007995.2018.1544119. Epub 2018 Dec 4. PMID: 30388895.

22. Waaseth M, Adan A, Røen IL, Eriksen K, Stanojevic T, Halvorsen KH, et al. Knowledge of antibiotics and antibiotic resistance among Norwegian pharmacy customers - a cross-sectional study. BMC Public Health. 2019 Jan 15;19(1):66. doi: 10.1186/s12889-019-6409-x. PMID: 30646892; PMCID: PMC6332570.
23. Yusef D, Babaa Al, Bashaireh AZ, Al-Bawayeh HH, Al-Riijal K, Nedal M, et al. Knowledge, practices \& attitude toward antibiotics use and bacterial resistance in Jordan: A cross-sectional study. Infect Dis Health. 2018 Mar;23(1):33-40. doi: 10.1016/j.idh.2017.11.001. Epub 2017 Nov 24. PMID: 30479302.

24. Alhomoud F, Aljamea Z, Almahasnah R, Alkhalifah K, Basalelah L, Alhomoud FK. Self-medication and self-prescription with antibiotics in the Middle East-do they really happen? A systematic review of the prevalence, possible reasons, and outcomes. Int J Infect Dis. 2017 Apr;57:3-12. doi: 10.1016/j.jij. 2017.01.014. Epub 2017 Jan 19. PMID: 28111172

\section{Amira Saad Badran}

\section{(Corresponding address)}

Faculty of Oral \& Dental Medicine, Misr International University, Cairo, Egypt.

Email: dr.amirabdrn@gmail.com 